\title{
NEMOC MLADÉHO HUMA A FILOSOFICKÁ KRIZE
}

\section{Hynek Janoušek}

David Hume je myslitelem, který se nezdráhá tvrdit, že filosofií si může člověk ublížit. Zranění nevzniká podle Huma tím, že adept filosofie nahlédne pouhé zdání, které mylně považuje za pravdu, nýbrž tím, že ho nazírání filosofických tezí - at' pravdivých či nepravdivých - odvede od širšího kontextu každodenně zakoušeného, mezilidského světa, a tím že nezohlední běžné podmínky možnosti intelektuální činnosti. Mluvíme-li zde o zranění, nemáme přitom na mysli pouze ublížení na duši, jež může vést k melancholii a deliriu, které, jak známo, Hume zmiňuje na jednom z klíčových míst Pojednání o lidské přirozenosti, ${ }^{1}$ nýbrž i reálný fyziologický neduh či poranění nervů, jež takové stavy doprovází. Stav mysli a stav těla totiž ,,spolu úzce souvisí“ ${ }^{2}$ V tomto textu nejprve rozebereme Humův Dopis lékaři, ${ }^{3}$ v němž lze odkrýt zárodek Humovy teorie duševní a tělesné krize vyvolané filosofickou činností. ${ }^{4} \mathrm{~V}$ druhé části článku pak zaměříme pozornost na hlubší filosofickou rovinu. Podíváme se, jak se celá problematika krize mysli při provozování filosofie vztahuje k Humovu pojetí entuziasmu a jak je u Huma v Pojednání začleněna do nauky o sociální povaze lidské přirozenosti. $V$ průběhu diskuse nahlédneme i do mladického Humova dopisu př́teli Michealu Ramseymu a do raných Humových esejů, sepsaných a publikovaných krátce po

1 D. Hume, Pojednání o lidské přirozenosti (= Pojednání), I, Rozum, přel. H. Janoušek, Praha 2015, 1.4.7.9. Číslice na konci citací z Pojednání udávají podle zavedeného zvyku číslo knihy, části, oddílu a odstavce, v němž se citát nachází.

2 Týž, To Dr George Cheyne. March or April 1734, in: týž, The Letters of David Hume, I, vyd. J. Y. T. Greig, Oxford 1932, str. 12-18, formulace se nachází na str. 16. Český překlad uvedeného textu lze najít v tomto čísle časopisu: D. Hume, Dopis lékaři, přel. H. Janoušek, str. 127-133.

3 Hume sám svůj dopis nenadepsal, jméno adresáta spekulativně doplnil editor Humových dopisů. V literatuře o Humovi se pro dopis standardně užívá název A Letter to a Physician. V naší studii budeme text citovat pod českým názvem Dopis lékaři, odkazovat budeme na stránky českého překladu.

4 Tuto část textu lze číst jako komentář k českému překladu uvedeného textu. 
vydání Pojednání. Konkrétně se jedná o eseje $O$ pověre a entuziasmu ( $O f$ Superstition and Enthusiasm), Skeptik (The Sceptic) a Epikurejec (The Epicurean). Všechny tři eseje Hume poprvé publikoval v roce 1741, rok po vydání třetí knihy Pojednání. Nauka Pojednání se v nich silně ozývá.

Výsledkem by mělo být správné pochopení „,nemoci z povolání“, která filosofovi podle mladého Huma hrozí. Oproti standardním výkladům Humovy filosofie se pokusíme ukázat, že podle Huma krize způsobená filosofickou činností původně nepramení ze skeptické povahy pravých filosofických náhledů. Plyne spíše z povahy entuziasmu, z abstraktní povahy předmětů filosofického uvažování vůbec a z toho, že se mysl vyznačuje sklonem k upadání do letargie, vůči němuž se musí bránit vyhledáváním silných vnějších vzruchů. Radikální skepse však tuto krizi ještě vyostřuje tím, že mysl připravuje o přístup $\mathrm{k}$ takovým typům podnětů, které mohou její intelektuální činnost dlouhodobě podporovat.

\section{O čem píše filosof lékaři?}

Hume napsal Dopis lékaři počátkem roku 1734 krátce před tím, než se pokusil nastoupit dráhu obchodního úředníka v Bristolu. Bylo mu dvacet tři let. ${ }^{5}$ Není známo, zdali dopis vůbec odeslal, a stejně tak není jisté, komu byl adresován. ${ }^{6}$ Dopis byl sepsán jako anonymní. Hume v něm popisuje

5 Dopis má z hlediska humovských bádání značnou hodnotu. Autor totiž lékaři podává, jak sám říká, jistou zprávu o celém svém dosavadním životě ve chvíli, kdy toto líčení ještě nepodléhá rozsáhlé reinterpretaci. Ta je patrná zejména v Humově krátké autobiografii Můj život (My Own Life), kterou napsal na sklonku svého života, v roce 1776. Z prvního období Humovy intelektuální činnosti, tj. z období před Humovým odjezdem do Francie v roce 1734, se zachovalo velmi málo písemností, které by dokládaly Humův myšlenkový vývoj. Kromě Dopisu lékaři se jedná jen o dva krátké dopisy Huma př́teli Michaelovi Ramsaymu, krátký text označovaný názvem Esej o rytírství (Essay on Chivalry) a několik poznámek a výpisků z četby, které bývají souborně označovány názvem Hume's Early Memoranda (viz E. Mossner, David Hume's „An Historical Essay on Chivalry and Modern Honour “, in: Modern Philology, 45, 1947, str. 54-60, a týž, Hume’s Early Memoranda 1729-1740, in: Journal for the History of Ideas, 9, 1948, str. 492-518). Tyto texty lze jen obtížně datovat.

6 Z dopisu je jasné, že adresát je Skot, známý lékař, vzdělanec a „muž ducha“, žije v Londýně či mezi Londýnem a Bristolem a zajímá se o filosofické otázky. Těmto charakteristikám podle badatelů odpovídají dvě osobnosti. Dr. George Cheyne a dr. John Arbuthnot. Prvního z nich identifikoval jako možného příjemce již první editor Humových dopisů John Burton (J. Burton, Life and Correspondence of David Hume, Edinburgh 1846, str. 42-47). Tvrzení, že adresátem je druhý jmenovaný, hájí autor nejznámějšího Humova životopisu Ernest Mossner (E. Mossner, Hume's 
vleklou nemoc psychosomatické povahy, která u něj propukla v roce 1729, kdy mu bylo osmnáct let. Tento popis je obsahově rozčleněn na čtyři části. Po 1) krátkém líčení svého raného intelektuálního vývoje až do chvíle propuknutí nemoci popisuje Hume 2) historii tělesných projevů své nemoci a 3) vývoj stavu své mysli a filosofických názorů (oba popisy se částečně prostupují). Dopis končí tím, že se Hume 4) dočasně vzdává filosofické činnosti a žádá o radu ohledně toho, zda a jak by se mohl zcela uzdravit. Ve vztahu autora k adresátovi se volně prolínají dvě roviny. Vztah pacienta k lékaři a vztah mladého učence k učenci již etablovanému. Hume proto lékaře informuje nejen o svých problémech, nýbrž také o filosofickém projektu, jehož realizaci stojí v cestě nemoc.

Podívejme se nejprve na bod 1. V Dopisu lékaři i v pozdní autobiografii Můj život Hume tvrdí, že ho obvyklá universitní výuka neoslovila. Propadl však literární vášni:

„Zjistil jsem, že se skoro stejnou měrou kloním jak k myslitelským a filosofickým dílům, tak k poezii a krásné literatuře..."7

„... v útlém věku jsem propadl vášni pro literaturu. Ta se stala vůdčí vášní mého života a hojným zdrojem mého potěšení.“8

Epistle to Dr. Arbuthnot, 1734. The Biographical Significance, in: Huntington Library Quarterly, 7, 1944, str. 135-152). Debatu ohledně adresáta shrnul John Wright, který zpochybňuje Mossnerovy závěry a uvádí, že pravděpodobnějším adresátem byl Cheyne. Podle Wrighta však současný stav bádání nedovoluje tuto otázku zcela jistě rozhodnout (viz J. Wright, Dr. George Cheyne, Chevalier Ramsay, and Hume's Letter to a Physician, in: Hume Studies, 26, 2003, str. 125-141). Důležité je, že popisy krize, které Hume lékaři předkládá, se nápadně podobají kazuistikám obsaženým ve známé Cheynově knize English Malady. Or, a Treatise of Nervous Diseases of all Kinds, as Spleen, Vapours, Lowness of Spirits, Hypochondriacal, and Hysterical Distempers, \& c., London - Bath 1733. Obzvláště se podobají Cheynovým popisům léčby jeho vlastní duševní a fyzické krize, viz J. Wright, Dr. George Cheyne, str. 126-127. Způsob, jak se Hume snažil vyléčit, téměř doslova odpovídá způsobu léčby, který si naordinoval Mandeville - ten jej popsal ve své knize A Treatise of the Hypochondriack and Hysterick Diseases z roku 1711. Viz také R. Wicker, Hume's Solution to Sceptical Melancholy, Montreal 2016, str. 29-30. Hume byl zjevně dobře obeznámen s literaturou podobného typu a uzpůsoboval jí popis svých potíží. Cheyne ovšem ve svých léčebných procedurách zacházel mnohem dál než Hume. Při četbě seznamu jedovatých substancí, které na sebe aplikoval (rtut', síra apod.), je z dnešního hlediska s podivem, že svou léčbu vůbec přežil (viz G. Cheyne, English Malady, str. 222-256).

7 D. Hume, Dopis lékaři, srv. níže, str. 128.

8 Týž, Můj život, přel. H. Janoušek, in: Filosofický časopis, 2, 2017, str. 176. 
V obou textech Hume navíc zmiňuje, že se původně rozhodl věnovat právu, avšak nedokázal se přimět $\mathrm{k}$ jeho souvislejšímu studiu a k četbě předepsaných autorů. Místo toho hltal filosofickou a krásnou literaturu, Cicerona a Vergilia. Zde však souběh textů končí. Celou více než pětiletou krizi, která přivádí mladého Huma k zoufalství a kvůli níž se dočasně vzdává učeneckého života, Hume ve stáří shrnuje již jen velmi lapidárně: „,... usilovná námaha poněkud podlomila mé zdraví, takže jsem byl sveden, či spíše donucen k tomu, abych podnikl velmi chabý pokus o aktivnější způsob života."9 Námaha, kterou Hume zmiňuje, je spojena s jeho odhodláním zcela zasvětit život filosofii a literární kritice. V roce 1727 , kdy mu je šestnáct let a kdy píše dopis př́iteli, ${ }^{10}$ ho již můžeme zastihnout, jak se plně věnuje tomuto cíli, v ústraní rodinného sídla v Ninewells. Z Dopisu lékaři víme, že v této době se v Humovi probouzí „bojovný duch“. Ve filosofii a v kritice čili nauce o kráse a správných zásadách krásných umění není podle Huma nic založeno, a snaží se tedy najít „,nový způsob, jakým by šlo stanovit pravdu“. ${ }^{11} \mathrm{~V}$ četbě přitom volně stř́ída filosofickou literaturu a klasickou poezii a pokouší se o vlastní filosofickou tvorbu, která má však značně fragmentární charakter:

„Veškerý mnou učiněný pokrok spočívá jen v načrtávání obrysů na volné listy papíru, zde zmínka o vášni, tam vysvětlený úkaz mysli, na jiné stránce změny v těchto vysvětleních, občas poznámka o autorovi, kterého čtu. V tom všem není nic cenného pro ostatní a myslím si, že sotva něco cenného pro mne."12

Jeho stav není bez vnitřních rozporů. V rodinném sídle, kde pobývá s ostatními členy rodiny a množstvím dalších lidí, je Hume, co se týče rozptýlení, „odkázán pouze na sebe a na knihovnu“ “, ${ }^{13}$ což na tomtéž místě dokládá latinským citátem - ea sola voluptas Solamenque ma$l i .^{14} \mathrm{~V}$ tomto období se pokouší o syntézu Ciceronových morálních

9 Tamt.

10 Týž, Letter to Michael Ramsay, July 4, 1727, in: týž, The Letters of David Hume, I, str. 9-11.

11 Týž, Dopis lékaři, srv. níže, str. 128.

12 Týž, Letter to Michael Ramsay, str. 9.

13 Tamt.

14 „Tot' jediná rozkoš, jediná útěcha v strastech.“ Vergilius, Aeneis, přel. O. Vaňorný, Praha 2018, str. 95. 
ponaučení a Vergiliovy bukolické poezie. Činí tak mimo jiné s ohledem na III. knihu Ciceronových Tuskulských hovorů o zmírňování zármutku:

„Co mi vryje do paměti lépe tuskulský rozhovor z Ciceronova $D e$ aegritudine lenienda než Vergiliova ekloga nebo georgika - filosofův mudrc a básníkův rolník sdílí mír v duši, svobodu a nezávislost na osudu, pohrdání bohatstvím, mocí a slávou. Vše je v nich zklidněno a ztišeno, nic v nich není nepokojné a narušené: At secura quies \& nescia fallere vita / Speluncae, vivique lacus, at frigida Tempe / Mugitusque boum, mollesque sub arbore somni / Non absunt. Tyto řádky se podle mne zcela vyrovnají ponaučení z nejlepších Ciceronových výroků." ${ }^{15}$

Mladičký Hume se touto syntézou snaží nalézt štěstí a stoický klid, nedaří se mu to však zcela:

„Saturnského štěstí jsem do značné míry dosáhl, ... klid mé mysli však není natolik stvrzen filosofií, aby vydržel rány osudu, takovouto velikost a vznešenost duše lze nalézt pouze ve studiu a kontemplaci, pouze to nás může naučit dívat se z výše na lidské nehody. “16

V této kontemplaci chce Hume prožívat extatické vytržení ze vznešeného a podle instrukcí z pseudo-Longinova Pojednání o vznešenu chce vznešeně i psát: ${ }^{17}$

„... čtu Longina a nalézám v něm veliké zalíbení, myslím, že jeho povaha skutečně odpovídá velké vznešenosti, kterou popisuje. Své rady poskytuje s takovou silou, jako by byl tímto tématem [vznešenosti] očarovaný. Je tvůrcem, který může být citován jako př́klad svých pravidel kýmkoli, kdo by měl dost odvahy o tomto tématu psát." ${ }^{18}$

15 D. Hume, Letter to Michael Ramsay, str. 10. Český překlad básně použité v citátu: „Zato má bezpečný klid, má úskoků neznalý život,/ doma má hojnost všeho, má poklid na širých polích,/ jeskyně, jezera živá a krásná údolí chladná,/ veselé bučení skotu a lahodný pod stromem spánek vždycky tam má." Vergilius, Zpěvy rolnické a pastýřské, přel. O. Vaňorný, Praha 2008, str. 39.

16 D. Hume, Letter to Michael Ramsay, str. 10.

17 Autor spisu je neznámý. Longinovi spis připisovala stř̌edověká tradice, které se Hume drží.

18 D. Hume, Letter to Michael Ramsay, str. 11. 
Četba pseudo-Longina dokládá Humův živý zájem o rétoriku a literární kritiku. Jaké rady se mu od tohoto autora dostává? Hume má podle pseudo-Longina aplikovat velké a vzletné pojmy, psát s mohutným a nadšeným citem, vhodně tvořit myšlenkové a slovní figury, dobře volit slova a obraznou mluvu a používat důstojný a povznesený slovosled a větnou skladbu. ${ }^{19}$ Je zřejmé, že byt' se mladý Hume již snaží o popis duševních pochodů, od skeptického a naturalistického východiska svého Pojednání o lidské přirozenosti je ve svých prvních filosofických pokusech velmi vzdálen. I když se jeho názory zajisté vyvíjely, není snadné uvěřit (ovšem nelze to ani vyloučit), že v roce 1729 , tedy již po roce a půl, dospěl k centrální nauce první knihy svého Pojednání, tj. k učení o asociativním předávání živosti z impresí na ideje, jež vede $\mathrm{k}$ živému pojetí idejí čili k vîre (belief) ${ }^{20}$ Humovi se sice podle Dopisu lékaři někdy kolem osmnáctých narozenin zdálo, že se před ním „,konečně otevírá nová krajina“ myšlení, která ho „naprosto uchvátila“. ${ }^{21}$ Tato charakteristika však může mít, jak dokládá Reinhard Brandt, pro Huma negativní konotaci. ${ }^{22}$ Hume se po této uchvacující krajině chvíli prochází a následně se u něj

19 Dionysiưv neb Longinův spis „O vznešenu“, přel. V. Sládek, Praha 1931, str. 18-19.

20 N. K. Smith, The Philosophy of David Hume, London 1960, str. 14-15.

21 D. Hume, Dopis lékaři, srv. níže str. 128.

22 R. Brandt, The Beginnings of Hume's Philosophy, in: G. Morice (vyd.), David Hume. Bicentary Papers. Edinburgh 1977, str. 117-127. Hume jednak kvalifikuje „,novou krajinu myšlení“ slovem „,seemed“, není tedy jasné, zda šlo skutečně o průlom v jeho myšlení, anebo jen o iluzi. Brandt si navíc všiml, že tentýž obrat ,scene of thought“ používá Hume v Pojednání negativně, a to ve smyslu nebezpečí pověr a vznícené obraznosti (viz Pojednání 1.14.7.13). Hume, jak uvidíme a jak si všímá i Brandt, v Dopise lékaři zcela jednoznačně umíst'uje svou myšlenku vědy o lidské přirozenosti do roku 1731. Za tuto interpretaci se opatrně postavil i M. A. Stewart, Hume's Intellectual Development, 1711-1752, in: M. Frasca-Spada - P. J. E. Kail (vyd.), Impressions of Hume, Oxford 2005, str. 29. Slavná teze Kempa Smithe, že Hume vstoupil do filosofie studiem morální filosofie, je sice pravdivá, ale jen zčásti. V roce 1727 se Hume celým stylem vyjadřování a charakterem své činnosti zdá být stále spíše žákem Shaftesburyho než Hutchesona (jak Shaftesburyho Characteristicks of Men, Manners, Opinions, Times (1711), tak Hutchesonovo An Inquiry into the Original of Our Ideas of Beauty and Virtue (1727) Hume v roce 1727 vlastnil). Shaftesbury radil čtenářům návrat k starověkým moralistům a pravému pojetí ctnosti, zkoumání sebe sama, a to i formou zápisu svých reflexí, a nabádal k rozjímání (viz M. A. Stewart, Hume's Intellectual Development, str. 38). Podíváme-li se na text Dopisu lékaři, pak Kemp Smithova teze předpokládá, že Hume základní myšlenku své teoretické filosofie objevil dříve, než prohlédl hypotetickou povahu antické morální filosofie a připadl na myšlenku nezaujatého a bezpředsudečného zkoumání lidské přirozenosti. 
objevují psychosomatické projevy nemoci, kterou bychom dnes nejspíše vágně nazvali syndromem vyhoření či únavovým syndromem.

První příznaky nemoci se dostavily v zárí 1729. Jakmile se Hume pokouší tvořit, přepadá ho únava a skleslost, je extrémně hubený, na rukou se mu objevují skvrny od kurdějí, trpí ptyalismem, tj. nadměrným sliněním. Následujících devět měsíců, tj. do června 1730, se Hume pokouší krizi překonat zvýšeným pracovním úsilím. V dubnu 1730 se radí s lékařem v Edinburghu, který mu diagnostikuje „,chorobu učených“ (disease of the learned) čili melancholii pramenící ze slabosti či subtilnosti nervů a vzlínání tělesných par. Ta podle dobového přesvědčení postihuje zejména učence kvůli nevhodnému tělesnému režimu a př́lišné intelektuální námaze. S touto diagnózou by však, jak poznamenala Margaret Watkinsová, ${ }^{23} \mathrm{v}$ Humově době od lékaře pravděpodobně odešel každý vzdělanec stěžující si na psychosomatické problémy.

Hume svou diagnózu přijímá opatrně a s rezervou, uvědomuje si však, že jeho život je příliš jednostranně zaměřen na studium a literární tvorbu. Začíná si postupně dopřávat zábavu, při práci šetří své síly, bere kapky a „tablety proti hysterii“, jezdí na koni a pije přiměřeně víno. V zimě 1730-1731, kdy v souladu s rodinným zvykem pobývá se svými bližními v Edinburghu, cítí návrat sil. V létě 1731 se vrací na venkov, je přátelštější ke svému okolí, chce opět začít pracovat, problémy však přetrvávají. „Shledal jsem, že nedokážu sledovat jediný řetězec úvah na jeden zátah, aniž bych se často zastavoval a příležitostně odpočíval při pohledu na jiné věci.“" ${ }^{24}$ Konečně se na jaře 1734, tj. pět a půl roku po propuknutí nemoci, rozhoduje dočasně upustit od realizace svých literárních plánů a vyzkoušet aktivnější život. Volí práci u obchodníka v Bristolu „odhodlán zapomenout na sebe a na celou svoji minulost, vrhnout se, jak jen to jde, do tohoto způsobu života a protloukat se světem od pólu k pólu, dokud [ho jeho] nemoc neopustí“ “. ${ }^{25}$ Cestou do Bristolu píše lékaři o radu, přičemž z dopisu je znát zoufalství: ,Znáte mezi všemi těmi učenci, s nimiž se stýkáte, někoho, kdo by byl stejně postižen? Mohu vůbec doufat v uzdravení? Budu na něj muset čekat ještě dlouho?“26

23 M. Watkins, Beyond the „Disease of the Learned“. Hume on Passional Disorders, in: P. A. Reed - R. Vitz (vyd.), Hume's Moral Philosophy and Contemporary Psychology, New York 2018, str. 11.

24 D. Hume, Dopis lékaři, str. 131.

25 Tamt., str. 133.

26 Tamt. 
Rozeberme nyní tu rovinu dopisu, v níž se mladý Hume obrací na lékaře jako jeden učenec na druhého. Občas se v literatuře hovoří o rané stoické krizi mladého Huma. Ten však v Dopisu lékaři neodmítá samotná stoická či stoicizující ponaučení a snahu se jimi řídit: „Tyto úvahy [Cicerona, Seneky a Plútarcha] jsou nepochybně velice užitečné." ${ }^{27}$ Spíše odmítá nesoudnou aplikaci těchto ponaučení a chabé základy nauky o lidské přirozenosti, z nichž vycházejí. Stoické náhledy se podle Huma musí pojit s aktivním životem, který $\mathrm{k}$ jejich uplatnění dává podnět. ${ }^{28}$ Úvahy o marnosti světské slávy a bohatství však, jak Hume záhy zjišt'uje, působí upřímně, pouze pokud je formulují lidé, ,jichž se svět a sláva týkaji““. ${ }^{29}$ Své vlastní meditace nad světskou marností označuje neznámý a chudý Hume v Dopisu lékaři za žlučovité (peevish) a zbytečné. Zároveň informuje lékaře o novém obratu svého filosofického úsilí. Většina filosofů minulosti propadla velikosti svého ducha, povahu lidské přirozenosti si spíše vymýšleli, než aby ji popisovali na základě bezpředsudečných pozorování. Morální filosofie, tj. filosofie člověka, kterou nám staří filosofové přenechali, je zcela hypotetická. Vědu o člověku je nyní třeba založit na novém, experimentálním základě. Humovu záměru se však opět staví do cesty nemoc:

„... během těchto tří let jsem, jak mohu konstatovat, popsal mnoho archů papíru, které neobsahují nic než mé vlastní objevy. Připočteme-li četbu nejvyhlášenějších děl v latině, francouzštině a angličtině a osvojení si italštiny, mohl byste to považovat za dostatečné zaměstnání pro zcela zdravého člověka, a také by tomu tak bylo, kdyby to $\mathrm{k}$ něčemu vedlo.“30

27 Tamt., str. 129.

28 Tamt.

29 Tamt., str. 132.

30 Tamt., str. 131. Stojí za zmínku, že tyto archy pravděpodobně obsahovaly Humovo první vyrovnání se s theismem a přirozenou theologií, které o dvacet let později (v roce 1751) zmiňuje v dopisu Gilbertu Elliotovi z Minta: „Před nedávnem jsem spálil rukopis staré knihy, kterou jsem napsal, než mi bylo dvacet, a která stránku po stránce zaznamenávala postup mých myšlenek na toto téma [přirozené theologie]. Začínala úzkostlivým hledáním argumentů podporujících běžné mínění. Postupně se dostavily pochybnosti, rozplynuly se, zase se vrátily. Šlo o neustálý boj nepokojné obraznosti se sklonem, možná že i s rozumem." D. Hume, To Gilbert Elliot of Minto, in: J. Y. T. Greig (vyd.), The Letters of David Hume, I, str. 145. 
Toto zhroucení ohrožuje Humovy životní plány: „Ztratil jsem naději, že své názory podám natolik elegantně a vybroušeně, abych $\mathrm{k}$ sobě přitáhl pozornost učeného světa, a raději budu žít a zemřu v zapomnění, než abych je plodil zmrzačené a nedokonalé."31 Hume se naštěstí bud' ještě v Bristolu, nebo později ve Francii vyléčil. Vzhledem k tomu, že následující tři roky strávené ve Francii intelektuální prací na Pojednání označuje Hume navzdory svému skromnému finančnímu zajištění za „velmi př́jemné“ , 32 je pravděpodobné, že nezapomněl práci vyvažovat odpočinkem a společenským rozptýlením.

\section{Entusiasmus a letargie v Humově Pojednání o lidské prirozenosti a dalších raných textech}

Viděli jsme, že Hume v první fázi své filosofické dráhy prožíval poetické nadšení, které spojoval s povznášející filosofickou kontemplací a teoretickými pozorováními. Není jistě náhoda, že se Hume po svém zhroucení vyjadřuje o dlouhodobé a izolované excitaci mysli poezií a filosofickou činností jako o stavu, který může být nebezpečný a problematický. V úvahách o tomto riziku se ukazuje být významný ještě třetí typ nadšení - nadšení náboženské. V Dopisu lékaři je tento náboženský entuziasmus a jeho fyziologický dopad na mysl př́mo zdrojem Humova podezíravého vztahu k filosofickému entuziasmu:

„Všiml jsem si, že když francouzští mystici a naši místní fanatici ve svých spisech popisují vývoj stavu svých duší, zmiňují netečnost a ztrátu duševních sil, jež se často vrací a jež některé z nich zpočátku mnoho let trápí. Jelikož tento typ zanícení zcela závisí na síle vášní a v posledku tedy na životních hybatelích [animal spirits], často jsem myslíval na to, že jejich a můj př́ípad si do značné míry odpovídají a že jejich extatické uctívání může narušit stavbu nervů a mozku podobně jako hluboké úvahy a vřelost či nadšení, které od nich nelze oddělit.“"33

Hume si popisy náboženských stavů dává dohromady s dobovou fyziologií. Problémem je v jeho očích zejména prudkost této extáze, které

31 D. Hume, Dopis lékaři, str. 131.

32 Tamt.

33 Tamt. 
odpovídá prudký pohyb látky v nervech. Ten tyto nervy po jisté době narušuje. Tato prudkost je $\mathrm{v}$ Humových raných textech často spojována s pojímáním neobvyklých a vznešených idejí excitovanou obrazností:

„V tomto [náboženském] stavu mysli obraznost přetéká vznešenými, avšak zmatenými pojetími, kterým nemohou odpovídat žádné sublunární krásy a žádná potěšení. Vše smrtelné a pomíjivé ustupuje jakožto nehodné pozornosti. “34

Analogie filosofického a náboženského nadšení ovlivňuje v Dopisu lékaři Humovo posouzení vlastní situace. Jestliže má zranění způsobené nadšeným provozováním filosofie fyziologickou povahu, může vyléčení přinést snad jen dočasné zanechání filosofických reflexí a následná regenerace nervů.

Druhým často zmiňovaným typem nadšení, které ovlivňuje Humovo pojetí filosofického entuziasmu, je nadšení básnické či poetické. Od filosofického a náboženského entuziasmu se liší tím, že vášněmi prostoupená živá obraznost, která je jeho zdrojem, nevytváří soudovou víru či přesvědčení: „At' již básnický entuziasmus rozruší životní hybatele jakkoliv, jedná se o pouhý stín víry či přesvědčení. “35 Tato živost, jak nás Hume upozorňuje v dodatku k Pojednání, se díky tomu pocitově liší od živosti víry: „, [živost idejí je zde] nahodilou okolností, ... fikci se takříkajíc propůjčujeme“. To však nestojí v cestě mocnému a prudkému účinku poezie: ,živost vytvořená fantazií v mnoha případech předčí živost pocházející ze zvyku a zkušenosti“ “. ${ }^{36}$ Zde se však také skrývá riziko možné záměny obou druhů živosti idejí:

„Pokud obraznost získá kvůli mimořádnému vření krve a životních hybatelů takovou živost, že to naruší všechny její síly a schopnosti, není jak odlišit pravdu od nepravdy. Protože působí stejně, je každá nezávazná smyšlenka nebo idea postavena na roveň impresím paměti a závěrům úsudků a účinkuje na vášně silou, jež se jejich síle vyrovná." ${ }^{37}$

34 D. Hume, Of Superstition and Enthusiasm, in: týž, Essays Moral, Political, and Literary, vyd. T. H. Green, Indianapolis 1985, str. 74.

35 Týž, Pojednání, 1.3.10.10.

36 Tamt., 1.3.10.8.

37 Tamt., 1.3.10.9. 
Nejeden autor vybavený silnou obrazností se tak může stát „obětí svého zanícení a své duchaplnosti“. V takovém stavu dochází k zaměňování fikce a reality. ${ }^{38}$ Navzdory rozdílu v druhu živosti idejí poetické obraznosti, v níž jsou realita a fikce odlišeny, a šílené obraznosti, v níž se fikce a realita prostupuje, vidí Hume mezi básnictvím a šílenstvím jistou analogii: „Básnictví i šílenství mají společné to, že živost, kterou udělují idejím, nevzniká z konkrétních vztahů a spojení předmětů těchto idejí, nýbrž z momentálního osobního rozpoložení a nálady. “39 Společným rysem poetického entuziasmu a entuziasmu náboženského a filosofického je, že živost předmětů nadšení má svůj zdroj ve vlastní činnosti obraznosti, jež je vedena vášněmi a náladami, a nikoli v živosti, kterou by obraznost pouze pasivně přijímala $\mathrm{z}$ impresí a převáděla na asociované ideje. Odtud se odvíjí i přenesený význam řeči o živé či vznícené obraznosti jako obraznosti, která dodává idejím živost z vlastních zdrojů.

Hume bohužel podrobněji neanalyzuje, proč jisté filosofické ideje začnou v diskursivní činnosti obraznosti působit velkolepě - jistou roli hraje zajisté rétorická vznešenost, s níž někteří filosofové dovedou své názory podat. Jako analogický příklad však může čtenáři posloužit Humova analýza posilování prožitku vznešenosti či hodnoty časově a prostorově vzdálených předmětů. Jestliže je naše obraznost aktivní a živá a vzdálenost natolik velká, že se dostává na hranu naší každodenní představivosti, je pro obraznost obtížné pojetí vzdáleného předmětu výzvou, jejíž zvládání vede k povznesení (elevation) představivosti a ke kvalifikaci předmětu pojetí pocitem vznešenosti, který z tohoto povznesení pramení. Předměty z dávných dob a dalekých krajin proto na základě takto živého pojetí působí velmi živě a vzbuzují silné vášně. ${ }^{40} \mathrm{Z}$ výše citované Humovy poznámky o nedostatečnosti „sublunárních krás a potěšení při srovnání světa a božství lze snad odhadnout, že i v zobrazování některých

38 Od tohoto patologického prostupování fikce a reality Hume odlišuje legitimní využití faktů a zvykem upevněných představ, převzatých např. z řecké mytologie, k posílení poetického účinku díla. „Básníci si vytvořili cosi, co nazývají poetickým systémem věcí. Ačkoliv v něj nevěří ani básníci, ani čtenáři, je běžně považován za dostatečný základ jakékoliv fikce... Právě tak si autoři tragédií vypůjčují své př́iběhy, anebo přinejmenším jména hlavních hrdinů z nějaké známého úseku dějin, a to nikoli kvůli klamání diváků, ... nýbrž kvůli tomu, aby představivost snadněji přijala pozoruhodné události, o kterých vyprávějí.“ Tamt., 1.3.10.6.

39 Tamt., 1.3.10.10.

40 Tamt., 2.3.8. Viz také E. Lecaldano, Hume's Sentimentalism and the Moral Sublime, in: A. Vaccari - L. Greco (vyd.), Hume Readings, Rome 2012, str. 182. Překvapivě skoupé Humovy poznámky na téma vznešenosti shrnuje E. Neill, Hume’s Moral Sublime, in: British Journal of Asthetics, 3, 1997, str. 246-258. 
náboženských a filosofických idejí by tyto předměty podle Huma mohly generovat povznášející pocit v limitním napínání obraznosti.

Kromě vznešenosti však může podle Huma filosofické nadšení vyvolávat samotná fascinace intelektuálními hádankami, jejichž řešení je spojené s nadějí na zodpovězení otázek, které považujeme za obzvláště důležité. ${ }^{41}$ Zdá se, že zatímco v nejranějších Humových dopisech stojí okouzlení „velkými“, krásnými a vznešeně podanými morálními a metafyzickými idejemi na stejné úrovni s nadšením pro řešení empirických otázek spojených s důležitými principy lidské přrirozenosti, v Pojednání role filosofického nadšení ze vznešeně a velkolepě působících pojmů ustupuje stranou a dominuje nadšení z nadějeplného hledání základních principů morální filosofie. Obě polohy se s ohledem na morální filosofii dostávají ke slovu v posledním odstavci základního textu Pojednání, kde Hume odlišuje filosofa jako anatoma lidské přirozenosti prostředkujícího užitečné pravdy, které mohou být dokonce odpudivé, od filosofa jako malîre této přirozenosti, který uchvacuje obraznost působivými rétorickými obrazy morální ctnosti a neřesti. ${ }^{42}$ Živá představivost a sklon propadat nadšení z předmětností určitého druhu je podle Huma naším vrozeným povahovým rysem. ${ }^{43}$ Zatímco v poetickém nadšení se mysl obrací a oživuje fiktivní svět osob, předmětů a dějů, v nadšení filosofickém je předmět myšlení „,abstraktní“ idejí, v čemž, jak ještě uvidíme, se podle Huma skrývá jistý problém.

Dříve než se tomuto problému budeme věnovat, pokusíme se dosavadní analýzu Humova přístupu k hrozbě skrývající se v provozování filosofie doplnit tím, že zohledníme tezi o přirozeném sklonu mysli k apatii z Pojednání o lidské přirozenosti.

Př́čciny možné duševní krize pocházející z provozování filosofie jsou v Pojednání a v raných esejích probírajících filosofickou činnost začleněny do hlubšího obrazu krize pramenící z mysli samé. Tento obraz je málo známý, zejména z toho důvodu, že některé jeho základní části se nacházejí v málo čtené druhé knize Pojednání a nejsou tak zrretelné v pozdějších Humových textech. V druhé knize Pojednání Hume hovoří o přirozeně nedostatečné schopnosti lidské mysli snášet nedostatek podnětů a osamění. Lidská mysl podle Huma upadá do netečnosti a zoufalství, když postrádá silné vnější vzruchy:

41 D. Hume, Pojednání, 2.3.10.3-4.

42 Viz tamt., 3.3.6.6 a repríza této myšlenky in: týž, Zkoumání o lidském rozumu, přel. J. Moural, Praha 1996, str. 23-24.

43 Týž, Pojednání, 1.4.7.14. 
„Lidé, kteří rádi kritizují lidskou přirozenost, tvrdí, že člověk vůbec není soběstačný a že jakmile narušíme jeho lpění na vnějších předmětech, okamžitě propadne nejhlubší melancholii a zoufalství. Odtud, tvrdí, pramení ono neustálé hledání zábavy ve hrách, při lovu či v zaměstnání, kterými se pokoušíme rozptýlit a vytrhnout naše životní hybatele z apatického stavu, do něhož upadají, když je v chodu neudržuje nějaká čilá a živá emoce. S tímto myšlenkovým pochodem do jisté míry souhlasím, nebot' připouštím, že mysl se sama nedokáže zabavit a přirozeně vyhledává cizí předměty, které by mohly vyvolat živý vjem a rozproudit životní hybatele.“"44

Jedním z možných způsobů, jak uniknout z této situace, je podle Huma právě podnětná intelektuální činnost, zejména jestliže nám skýtá naději na zodpovězení užitečných otázek.$^{45}$ Předměty myšlení jsou však pouhé ideje, čímž se otevírá otázka jejich vztahu k impresionálnímu světu vnější skutečnosti. Pokud je cílem filosofie nalézt ideje, jež se nevztahují k předmětům vnějšího, společně sdíleného světa a skutečné povaze lidské přrirozenosti a jež nemají žádnou užitečnost, a pokud chce filosofie tím, že si bude takové ideje osvojovat a že je bude rozvíjet, dospět k ukotvení lidského života a ke štěstí, začne mysl postupně ztrácet

44 Tamt., 2.2.4.4. Humův esej $O$ tragédii umožňuje konstatovat, že tuto teorii přebírá od Jeana-Baptisty Dubose, dobově neobyčejně populárního myslitele zabývajícího se emocionálním účinkem umění. Hume čerpal zejména z prvních dvou kapitol Dubosovy knihy Réflexions critiques sur la poésie et sur la peinture, která vyšla v roce 1719 v Paříži. Viz D. Hume, Of Tragedy, in: týž, Four Dissertations, London 1757, str. 186-187. Autoři jednoho z mála článků o vlivu Dubose na Pojednání, J. O. Young a M. Cameron, nemuseli spekulovat, že ,,podoba mezi úseky textů je taková, že se nemůže jednat o náhodu“ (J. O. Young - M. Cameron, Jean-Baptiste Du Bos' Critical Reflections on Poetry and Painting and Hume's Treatise, in: British Journal of Aesthetics, 2, 2018, str. 153). V eseji $O$ tragédii totiž Hume Dubose jako zdroj této teorie explicitně zmiňuje: „Abbé Dubos ve svých úvahách o poezii a malířství tvrdí, že všeobecně vzato je pro mysl ze všeho nejnepř́íjemnější mdlý, nehybný stav netečnosti, do kterého upadá, když přijde o všechny vášně a zaměstnání. Aby se tohoto bolestivého stavu zbavila, hledá jakoukoli zábavu a zaměstnání obchod, hazard, představení, podívanou na popravy, prostě vše, co vybudí vášně a odvede pozornost od ní samé. Na vášni nesejde, bud’si klidně nepříjemná, bolestná, smutná, narušená, pořád je to lepší než netečná zemdlelost, která vzniká z naprostého klidu a odpočinku. Není možné popřít, že tento výklad je přinejmenším zčásti uspokojivý.“ D. Hume, Of Tragedy, str. 186-187.

45 Stojí za zmínku, že podle Huma filosofie sdílí mnoho společných rysů s lovem, který je jmenován výše mezi zabavujícími činnostmi, viz D. Hume, Pojednání, 2.3.10.8. 
schopnost podporovat sebe samu ve své činnosti, nebot' jí k další činnosti schází podněty. Mnoho starověkých filosofů podle Huma tuto základní nesoběstačnost lidské mysli přehlíželo a jejich návod na nalezení štěstí v kontemplativní autonomii ducha tak ve skutečnosti vede k pravému opaku. Obzvláště silně tento názor zaznívá v Humově pohledu na obecnou povahu epikureismu a skepticismu, který nalézáme $\mathrm{v}$ jeho raných esejích:

„Pryč tedy se vším tím marným předstíráním, že se činíme št’astnými v nitru nás samých, že hodujeme na svých vlastních myšlenkách, že nás uspokojuje vědomí dobrého jednání a že pohrdáme veškerou pomocí a podporou od vnějších předmětů... Nepodporována vhodnými předměty, upadá mysl do nejhlubšího smutku a sklíčenosti. Bídný, ale pyšný člověče! Necht' je tvá mysl št’astná sama v sobě! Jakými zdroji je ale vybavena, aby zaplnila tak ohromnou prázdnotu a zastoupila všechny tvé tělesné smysly a schopnosti? ... Když jí schází vnější zaměstnání a radosti, musí se mysl zřítit do letargie a melancholie.“46

Tento odvrat od světa může zpočátku vést k filosofickému nadšení z nové intelektuální krajiny nabízející vznešené ideje, jež slibují osvobození od závislosti na vnějších stimulech a spolu s tím i rozřešení zásadních otázek a problémů lidského života. Viděli jsme, že prudkost tohoto nadšení může, přinejmenším podle nejranějších Humových reflexí, dokonce vést i k nervovému přepětí. Abstraktní ideje, které oživuje pouze vzrušená obraznost, jsou však příliš slabé na to, aby mysl samy o sobě trvale podněcovaly. Výsledkem je postupný nárůst apatie a melancholie, kterému po fyziologické stránce odpovídá ochabnutí původně prudkého pohybu životních hybatelů:

oddání se filosofii, právě tak jako entuziasmus básníka, je přechodným účinkem vybuzených hybatelů, velkého množství volného času, citlivého ducha a studijního a kontemplativního návyku. I když jsou však dány tyto podmínky, abstraktní, neviditelný předmět, jako například ten, který nám poskytuje přirozené náboženství, nedokáže dlouho podněcovat činnost mysli. “"

46 D. Hume, The Epicurean, in: týž, Essays Moral, Political, and Literary, str. 140 .

47 Týž, The Sceptic, in: týž, Essays Moral, Political, and Literary, str. 167. 
Filosofické nadšení doprovázející takto zaměřenou intelektuální činnost se sice může po jistém odpočinku obnovit, celý kruh se tím však pouze zopakuje a krize se spíše prohloubí. Myslitel, uzavřený v rytmu přepětí a skleslosti, prudkého vznícení životních hybatelů a následného ochabnutí, je tak zdánlivě postaven před volbu mezi filosofickou činností a jejím zavržením.

Je zjevné, že podle Huma obraznost dostatečně zaměstná pouze vnější předmět smyslů a vášní, který, řečeno s Humem, v mysli vystupuje jako imprese, a nikoli jako idea oživená obrazností samou. Předmětem, který se k tomuto účelu dlouhodobě hodí, může být podle Pojednání o lidské přirozenosti nakonec jen jiná lidská mysl, a to díky síle impresí, které nám prostředkuje princip sympatie čili vcit’ování do prožitků druhých lidí. Sympatie nám totiž poskytuje

„nejživější ze všech předmětů: rozumnou a myslící bytost, jako jsme my sami, která s námi sdílí všechna hnutí své mysli, zasvěcuje nás do svých nejniternějších pocitů a dojmů a umožňuje nám nahlížet na veškeré emoce vyvolávané předměty, a to v samotném okamžiku jejich zrodu. Všechny živé ideje jsou př́jemné, zejména však ideje vášní, nebot' takovéto ideje se stávají vášněmi a mysl vzrušují citelněji než všechny ostatní obrazy či pojetí.“48

Tím, že nás sympatie odvádí od nás samých k pocitům druhých, jde př́mo proti sklonu mysli k upadání do sebe samé: „... př̌i sympatii není naše osoba ani předmětem vášně, ani v ní nic nezaměřuje pozornost na nás samé“ “ ${ }^{49}$ Na sympatii pak závisí i živost našich vlastních vášní: ,... kdybychom zcela abstrahovali od myšlenek a pocitů druhých, neměly by [naše vášně] žádnou sílu“.$^{50}$ Opět neschází ani fyziologická stránka

48 Týž, Pojednání, 2.2.4.4.

49 Tamt., 2.2.2.17.

50 Tamt., 2.2.5.15. Filosoficky se význam sympatie ohlašuje např́íklad v důrazu, který Hume podobně jako Cicero klade na přátelství a přítomnost blízkých lidí. Jestliže jsme s druhým člověkem důvěrně obeznámeni, účinkuje sympatie na naši mysl živěji (tamt., 2.2.4.5). Hume přijímal celou řadu Ciceronových závěrů, domníval se však, že je třeba je nově založit tak, aby správně vyplývaly z popisu lidské přirozenosti. K tomu viz P. Jones, Hume's Sentiments. Their Ciceronian and French Context, Edinburgh 1982, str. 29-40. Tato živost se ještě posílí, jestliže je přirozené ladění obou myslí podobné. Sympatie proměňuje živé ideje pocitů druhých lidí v imprese: „K této proměně však dojde snadněji, pokud nás přirozenost naší povahy vybaví sklonem k pocit'ování stejné imprese, kterou pozorujeme u ostatních, a vyvolává 
vysvětlení: „Sympatie s druhými je př́ijemná pouze tím, že uvádí hybatele do pohybu. “51

Z řečeného zajisté nevyplývá, že by ostatní vnější vzruchy byly zbytečné, nýbrž že jsou samy o sobě nedostatečné, pokud je v rozmanitých ohledech nedoplňují výkony sympatie..$^{52}$ Oproti „lidem, kteří rádi kritizují lidskou přirozenost", tedy Hume nevidí v přirozeném pohybu mysli od sebe samé k silným vnějším vzruchům pohyb odcizení, nýbrž podmínku lidské sociálnosti a samotnou podmínku udržitelné činnosti mysli - „krev se vzedme, srdce buší a člověk se cítí živý způsobem, který je pro něj v klidných a osamělých chvilkách nedosažitelný. “533 Má-li být pro mysl její činnost vůbec snesitelná, musí ji, at’ chce, či nechce, oživovat pocity a názory druhých lidí.

Co platí pro činnost obecně, platí i pro veškerou intelektuální činnost a filosofii zvláště. Abstraktní předměty mysli filosofickému uvažování samy o sobě nestačí. Uvažování o nich sice musí být chápáno jako věcně prŕínosné, tj. důležité, pro veřejnost vůbec. Výsledek intelektuální činnosti pro ostatní je však podle Huma chápán jako hodnotný pouze na základě sympatie s užitkem myšlení, tj. na základě sympatie s reálnými či představovanými pocity a emocemi (obvykle anonymních a neznámých) recipientů myšlení, v jejichž zájmu se myšlení realizuje. ${ }^{54}$

Právě tak, jako rozum podle Huma není schopen určit dobro či zlo charakteru či jednání, není schopen sám o sobě určit užitečnost či neužitečnost předmětu. Libý pocit z předmětu, který označujeme jako užitečný, se konstituuje teprve na základě toho, co člověk chce či nechce. Když tedy podle Huma vidíme naprríklad neúrodnou zem, pramení bezútěšný pocit při pohledu na ni ze sympatie s pocity jejích skutečných či možných obyvatel.$^{55}$ Není nutné, aby při tom nějací lidé stáli vedle nás, na krajinu se můžeme dívat i sami.

Podobná sympatie prrirozeně doprovází a fixuje zaměření na předmět tvořivé intelektuální činnosti. Tato sekundární emoce vznikající ze

ji při sebemenší příležitosti. V takovém případě podobnost ... nabízí materiál, který podpálí i drobná jiskra.“ Tamt., 2.2.4.7.

51 Tamt.

52 Viz klasické vyjádření tohoto názoru u Huma v Pojednání, 2.2.5.15. Podrobný popis funkce sympatie a odkaz na další literaturu nalezne čtenář v: H. Janoušek, Sympatie a prostorovost vášní u Huma, in: Reflexe, 54, 2018, str. 79-103.

53 D. Hume, Pojednání, 2.2.4.4.

54 Tamt., 2.3.10.4-6.

55 Tamt., 2.2.9.17. 
sympatie je nutná k tomu, aby bylo teoretické myšlení schopné na svůj předmět dlouhodobě upírat pozornost. Jinými slovy, není možné myslet čistě pro sebe sama di̊ležitost výsledku myšlení, stejně jako není možné takto myslet důležitost žádného lidského výtvoru, nebot' ta je korelátem pocitů anonymního „vnějšího“ uživatele, od nichž se mysl nemůže odpoutat. Hume sám tvrdí, že tuto závislost lze snadno přehlédnout, sympatie nám v tomto případě totiž poskytuje pouhý stín vášně, která se pohybuje na hranici rozeznatelnosti: „Lze zajisté namítnout, že takováto vzdálená sympatie je velmi slabým základem vášně a že tolik píle a úsilí, které u filosofů často pozorujeme, nemůže nikdy plynout z takto bezvýznamného zdroje. “" ${ }^{66}$ Přesto je však pro zaměření myšlení na abstraktní předměty nepostradatelná: „Když necítíme zájem a jsme nepozorní, tatáž činnost chápavosti na nás vůbec nezapůsobí a nedokáže nám přinést nic ze slasti, která z ní plyne, když jsme v jiném rozpoložení. “57 Tuto slast či potěšení doprovázející myšlení však přirozeně potřebujeme, máme-li se intelektuální činnosti věnovat dlouhodobě a máme-li se vyhnout letargii a melancholii..$^{58}$

Co však vlastně Hume myslí onou abstraktní povahou filosofických předmětů, která nás může při nesplnění určitých podmínek zradit? ${ }^{59} \mathrm{Ve}$ svém raném díle na různých místech popisuje tuto povahu přinejmenším třemi různými způsoby.

V prvním významu znamená „abstraktní“ to co obecný, a Hume se v tomto ohledu staví proti klasické platónské tezi, podle níž lidské myšlení a jednání může významně oživovat a uvádět do pohybu čisté zření obecných idejí:

„Čím obecnější a univerzálnější však naše ideje jsou, tím méně zajisté působí na obraznost. I když obecná idea je pouze jednotlivou idejí uvažovanou z jistého hlediska, je obvykle méně jasná. Žádná

56 Tamt., 2.3.10.6.

57 Tamt.

58 Tato vazba na pocity, jež zprostředkovává sympatie, je pro filosofickou tvorbu nutná, není však zajisté dostatečná. Pravé věcné myšlení je vázáno metodickou reflexí zkušenosti, kterou se Hume pokouší představit ve svých pravidlech pro vedení rozumu ve vědách, viz Pojednání, 1.3.15. Samotné rozvíjení těchto pravidel však opět předpokládá jejich hodnotu pro lidi vůbec a je spojeno s Humovým osvícenským předpokladem hodnoty experimentálního založení věd pro lidstvo.

59 V následujícím se nebudeme zabývat abstrakcemi ve smyslu idejí, jimiž se podle Huma zabývá matematika, a zaměříme se jen na na abstrakce ve smyslu předmětů filosofických teorií, které jejich pomocí vysvětlují fakta. 
jednotlivá idea, jejímž prostřednictvím reprezentujeme obecnou, totiž není nikdy stabilní a pevně určená, nýbrž lze ji snadno zaměnit za jiné jednotlivé ideje, které ji v reprezentaci stejně dobře zastoupí.“60

Hume tento názor opírá o svůj nominalismus, jenž se snaží redukovat obecné ideje na třídy idejí partikulárních, které spojují vztahy podobnosti a které jsou asociovány se stejným jménem. Nepředstavujeme si tedy nikdy obecnou ideu, ale ideu jednotlivou. Jelikož jsme se však naučili uplatňovat stejné jméno na podobné ideje, zaslechnutí či vybavení tohoto jména vyvolává dispoziční vědomí dalších idejí, s nimiž je idea asociována a které by ji mohly zastoupit, kdyby se nám vybavily - z toho pramení ona nestabilita, o níž Hume v citátu výše hovoří. Tyto ideje „,pak nejsou přítomny mysli reálně a skutečně, nýbrž pouze potenciálně. V obraznosti si je rovněž nezobrazujeme zřetelně, nýbrž jsme stále připraveni zkoumat jakékoliv z nich podle toho, jak nás k tomu může pobídnout náš momentální úmysl či potřeba. “61

Slabost obecných idejí postihuje i vášně, jež na ně reagují. To se týká i obecných pojetí principů lidského jednání, jakým je např. spravedlnost:

„Themistoklés plánoval tajně zapálit flotilu všech řeckých obcí, která se shromáždila v blízkém přístavu a jejíž zánik by Atéňanům poskytl nikým neohrožovanou nadvládu nad mořem. Aristeidés se vrátil do shromáždění a oznámil mu, že nic nemůže být výhodnější než Themistoklův plán, zároveň však nemůže být ani nic nespravedlivějšího. Lid [který konkrétní obsah plánu neznal] následně plán jednohlasně odmítnul... Filosofové nikdy neváhají mezi volbou prospěchu a poctivosti, protože jejich rozhodnutí jsou obecná, a ani jejich vášně, ani jejich obraznost se o předmět nezajímají. Ačkoliv ve výše uvedeném případě byl prospěch Atéňanů bezprostřední, znali ho pouze pod obecným pojmem prospěchu, aniž by byl pojat konkrétní idejí. Proto musel na jejich obraznost působit méně a představoval menší pokušení, než kdyby byli seznámeni se všemi jeho okolnostmi. Jinak by bylo těžké si představit, že veškerý lid, nespravedlivý a násilný, jak lidé běžně bývají, by se tak jednoznačně držel spravedlnosti a odmítl obrovskou výhodu.“62

60 D. Hume, Pojednání, 2.3.6.2.

61 Tamt., 1.1.7.7.

62 Tamt., 2.3.6.3-4. 
Tato slabost ještě více postihuje ty obecné ideje, které nemohou být v oblasti lidské praxe př́imočaře provázeny sympatií s užitečností či př́ijemností pro druhé.

V druhém významu, který jsme již výše několikrát zmiňovali, znamená ,,abstraktní“ předmět totéž, co předmět odtržený či vzdálený od reality světa impresí a sympatie. Ideje fiktivních předmětů, domnělé ideje imateriálního, neviditelného božstva apod., to vše jsou v tomto ohledu abstraktní ideje, jež se jen velmi slabě, pokud vůbec, vztahují podobností nebo př́činností k řádu impresí, z nějž se podle Huma napájí naše víra v existenci nezávislého, trvajícího a společně sdíleného světa. Humův oblíbený př́íklad je víra v posmrtný život:

„Zatímco podobnost naše úsudky zesiluje, jestliže se spojí s př́íčinností, každý její významnější nedostatek je dokáže takřka úplně zničit... Není snad větší zdroj údivu učence a zármutku zbožného člověka než vidět nezájem většiny lidstva o věčný život a mnoho význačných teologů oprávněně neváhalo tvrdit, že byt' obyčejní lidé nesplňují formální znaky nevíry, ve skutečnosti jsou v jádře pohani... Nedostatek podobnosti v tomto př́ípadě skutečně likviduje víru tak dokonale, že kromě několika málo lidí, kteří si po chladném uvážení významu celé věci dali tu práci, aby opakovanými meditacemi do své mysli vtiskli argumenty ve prospěch věčného života, sotva existují další, kteří věří v nesmrtelnost duše na základě pravého a pevného úsudku..."63

Ve třetím ohledu označuje Hume jako „abstraktní“ všechny úvahy, které jsou složité či subtilní a které díky této povaze zatěžují obraznost natolik, že se její schopnost oživovat závěry těchto úvah vyčerpá. Dlouhé řetězce úsudků, i když je každý jejich krok oprávněný a jednoznačný, ,,dokonce vytváří přesvědčení jen zřídka a člověk musí mít velmi silnou a spolehlivou obraznost, aby jistotu, v případě, že prochází tolika kroky, udržel až do konce“. ${ }^{64}$ Hume, jak má příležitostně ve zvyku, řadí soudovou víru mezi emoce, $\mathrm{k}$ jejichž oslabení tyto úvahy svou náročností vedou.

63 Tamt., 1.3.9.13-14. V poněkud odlišném, ale př́íbuzném smyslu je pro Huma abstraktní i předmět radikální skepse. Úsudky zde neničí nedostatek podobnosti, nýbrž nedostatek víry ve skutečnost předmětu.

64 Tamt., 1.3.13.3. 
„Právě tak, jako nám emoce zabraňují subtilněji uvažovat a hloubat, narušuje subtilnější uvažování a hloubání stejnou měrou emoce. Mysl, zrovna tak jako tělo, je, zdá se, vybavena určitou přesnou mírou síly a aktivity, kterou je schopna vynaložit v jedné činnosti jen na úkor všech zbývajících... Není tedy divu, že přesvědčení pramenící ze subtilního uvažování klesá úměrně k úsilí, které obraznost vynakládá na to, aby pronikla do úvahy a pochopila všechny její části. Jelikož víra je živým pojetím, nemůže být nikdy naprostá, pokud nestojí na přirozeném a přístupném základě.“65

Hume se naukou o abstraktní povaze filosofických předmětů obrací proti stoicko-bukolickému nadšení svých filosofických počátků. Jistí lidé se rodí s citlivou obrazností, touhou po poznání a intelektuálních výzvách. „Ohnivé části“ “ ${ }^{66}$ které je utvárí, je vedou do světa abstraktních předmětů a úvah. ${ }^{67}$ Pokud mají tito lidé abstraktní povahu předmětů svého teoretického myšlení zvládat, musí být jeho ideje a otázky svázány s předměty tohoto světa a s pocitově prožívaným přijetím vlastního díla u dru-hých lidí.

\section{Závěrečná poznámka k filosofickému skepticismu Pojednání a výsledné podobě filosofie}

Jak známo, v první knize Pojednání dovádí Huma filosofická reflexe ke skeptickým závěrům. Je však zjevné, že podle Huma potenciální nebezpečí hrozí ze strany jakéhokoliv oddání se abstraktním úvahám, pokud odvádějí mysl od běžných předmětů víry a pokud umenšují význam vlastního myšlení a jeho výsledků pro druhé. U Huma mezi takové úvahy bezesporu patří kromě radikální skepse např. i dlouhodobé, špatně pochopené stoické opevňování ducha. Při četbě a interpretaci Pojednání o lidské přirozenosti je tedy třeba být opatrnější a neidentifikovat krizi, do níž nás filosofie může uvrhnout, pouze s radikálně skeptickou filosofií. Její základy v lidské přirozenosti jsou v Humově chápání obecnější.

Destruktivní síla radikálně skeptické filosofie, s jejímž vylíčením se setkáváme v závěru první knihy Pojednání, však celý problém

\footnotetext{
65 Tamt., 1.4.1.11.

66 Tamt., 1.4.7.14.

67 Viz D. Hume, Of the Delicacy of Taste and Passion, in: týž, Essays Moral, Political, and Literary, str. 3-8.
} 
myšlenkové potřeby vnějších vzruchů bezesporu potencuje a vyostřuje. Stěží si lze představit radikálnější popis narušení přirozených a instinktivní vírou podložených vazeb ke světu a k druhým než ten, který Hume podává při popisu skeptické krize v závěru první knihy Pojednání. Bolestný stav mysli zde pramení zejména ze ztráty přístupu k druhým lidem:

„Zprvu mne tato bezútěšná samota, do níž mne má filosofie přivedla, děsí. Připadám si jako nějaké podivné, neohrabané stvoření, které bylo, protože se nedokáže začlenit a vrůst do společnosti, vykázáno ze všech lidských styků a ponecháno naprosto opuštěné a nešt'astné.“68

Další, specifický problém radikálního skepticismu, který krizi dále prohlubuje, spočívá v tom, že pochybování nás připravuje o naději na získání obecně důležitých výsledků, tedy podíváme-li se na věc z Humovy perspektivy, zbavuje nás naděje na nalezení základních principů lidské přirozenosti.

Z Humovy nauky ale vyplývá, že do takového stavu mysl nepřivede nikdy jen momentální zohlednění radikálně skeptických argumentů, nýbrž vyčerpávající snaha o dlouhodobé kontemplativní podržení jejich platnosti, které se universálním zpochybněním víry ve skutečnost pokouší zabránit mysli v návratu k „Živým“ idejím faktických okolností a pocitům druhých lidí. Ničím nezmírňovaná abstraktní povaha předmětů skeptických úvah ve všech třech výše pojednaných významech sama vede $\mathrm{k}$ tomu, že mysl v ně nedovede soustavně věřit a vrací se zpět $\mathrm{k}$ přirozeným stimulům a vîre ve vnější a nezávislou existenci společně sdíleného světa. ${ }^{69}$ Pokud má být dlouhodobě tvořivá myšlenková činnost vůbec možná, nemůže se pohybovat v radikálně skeptickém rámci.

Na konci první a druhé knihy Pojednání nachází Hume pro filosofii východisko v obratu k teoretickým zkoumáním provozovaným v bezstarostném duchu. Tato filosofie je regulována obecným užitkem předkládané filosofické nauky, je věcně založená v lásce k pravdě a má ambici získat uznání kompetentních osob. ${ }^{70}$ Vztah ke společně sdílenému světu a působení v něm se tak stává nutnou podmínkou filosofie samé. Filosof nemůže soukromě opustit svět kulturně sdílené smyslové reality, aby získal hlubší, svět překračující ideové poznání, s nímž by se mohl, pokud

\footnotetext{
68 Týž, Pojednání, 1.4.7.2.

69 Viz tamt., 1.4.1.7.

70 Viz tamt., 2.1.11.11-13, 2.3.10.1.
} 
se pro to rozhodne, do veřejně sdíleného světa vracet. ${ }^{71}$ Složitou otázku ohledně popisu partikulární, radikálně skeptické podoby, kterou má v Pojednání krize filosofujícího jedince, a nástin jejího řešení obratem k umírněně skeptické filosofii, metodologii věd a zkoumání obecných principů lidské přirozenosti ve ,veřejném zájmu“, zde již však musíme ponechat stranou. ${ }^{72}$

Náš text měl mimo jiné ukázat následující. Představa, že otázka empirických principů praktikovatelnosti filosofie je věcí psychologie, která se nachází mimo oblast hlubokých filosofických témat, je př́liš zjednodušující. Každému, kdo se domnívá, že do první oblasti patří pouze banality typu ,abychom mohli vůbec myslet, musíme být dostatečně najedení, nesmíme být pod vlivem návykových látek“ apod., by Hume mohl položit např. následující otázky: Jaký subjekt prožívá libost, kterou filosof při myšlení cítí a kterou pro provozování filosofie potřebuje, nikoli jako cíl myšlení, nýbrž jako podmínku jeho možnosti? Kdo a proč se raduje, když myšlení postupuje úspěšně vpřed? Není filosofické myšlení spíše motivované specifickou vášní, která je, tak jako všechny vášně, podmíněna lidskou přirozeností? Může být tvoření myšlenkových soustav vůbec motivováno „čistým rozumem“, a pokud ne, jak by mohla vypadat čistá motivace intelektuálního jednání? Jak jsme viděli, u Huma ke správně pojatému osamělému myšlení bezpochyby patří silný intersubjektivní a praktický důraz, který je váže k světským potřebám jedince a společnosti a který je brání před nástrahami lidské přirozenosti. ${ }^{73}$

\section{ZUSAMMENFASSUNG}

Der erste Teil des Beitrags präsentiert einen Kommentar zu Humes berühmten Brief an einen Arzt unter besonderer Berücksichtigung der Frage nach dem psychologischen und physiologischen Einfluss von Enthusiasmus auf den menschlichen Geist. Der zweite Teil versucht die gewonnene Einsicht in ein breiteres Bild der Humeschen Auffassung des Geistes zu integrieren und zu vertiefen, das er in seinem Treatise of

71 Srv. tamt., 1.4.7.12 a 2.3.10.

72 Této otázce se podrobněji věnuji v recenzní studii $O$ skepticismu a filosofii u Davida Huma, in: Filosofický časopis, 4, 2020, str. 623-633.

73 Tento článek je výstupem grantového projektu GAČR 17-06904S Meze rozumu ve věku rozumu: spory ve filosofii 18. století, řešeného na Filozofické fakultě Univerzity Hradec Králové a na Filosofickém ústavu AV ČR. 
Human Nature und in einigen von seinen frühen Essays entwirft. Humes vorsichtige Einschätzung des philosophischen Enthusiasmus in seinem frühen Werk wird auf dem Hintergund seiner Auseinandersetzung mit dem religiösen und dichterischen Enthusiasmus analysiert. Ein starker Einfluss philosophischer Ideen auf die Vorstellungskraft scheint zunächst die inhärente Abhängigkeit des Geistes von externen Objekten zu verringern. Allerdings ist die abstrakte Natur der philosophischen Ideen nicht stark genug, um die Aktivität der Vorstellungskraft über längere Zeit hinweg anzuregen. Der vorliegende Beitrag behandelt drei Merkmale dieser abstrakten Natur der Ideen: den allgemeinen Charakter der philosophischen Ideen, die Abstrahierung von der wahrgenommenen Welt und die Komplexität der Argumentation. Weiterhin wird gezeigt, dass nach Hume die Tätigkeit der Sympathie gebraucht wird, um das philosophische Denken zu ergänzen und zu beleben, wenn es tragfähig sein soll. Diese Tätigkeit bindet die philosophischen Ergebnisse des einsamen Denkens an die Emotionen seiner Empfänger, so dass es unmöglich ist, isoliert von der Außenwelt zu denken. Der Beitrag behauptet weiterhin, dass radikale Skepsis zwar eine der schlimmsten Sünden gegen diese natürlichen Gefühle der Sympathie ist, die als Denkbedingungen anzusehen sind. Die Ursachen der potenziellen Krankheit, die durch philosophisches Denken verursacht wird, werden von Hume jedoch in einem umfassenderen Rahmen und nicht nur auf radikale Skepsis beschränkt behandelt.

\section{SUMMARY}

The first part of the article presents a commentary on Hume's famous letter to a physician, especially with respect to both the psychological and the physiological impact of enthusiasm on the human mind. The second part attempts to integrate and deepen the insights thus gained into a broader picture of Hume's concept of mind in his Treatise of Human Nature and in some of his early essays. Hume's cautious view of philosophical enthusiasm in his early work is analyzed against the background of his discussion of religious and poetic enthusiasm. The strong impact of philosophical ideas on the imagination initially seems to alleviate the mind's inherent dependency on external objects. However, the abstract nature of philosophical ideas is not strong enough so as to sustain the activity of the imagination over a longer period of time. The article discuses three features of this abstract nature: the general character of 
philosophical ideas; abstraction from the perceived world; and the complexity of arguments. It further shows that according to Hume, operations of sympathy are needed to supplement and invigorate philosophical thought if it is to be sustainable. These operations bind the philosophical results of lonely thinking to emotions of its recipients, thus making it impossible to think in isolation from the outside world. The text also argues that while radical skepticism is one of the worst sinners against this natural "sympathetic" condition of thinking, the causes of the potential malady caused by philosophical thought are conceived by Hume more broadly and not as exclusively limited to radical skepticism. 